\title{
ANALISIS FAKTOR-FAKTOR YANG BERHUBUNGAN DENGAN ASUPAN MAKANAN PASIEN THALASEMIA DI RSUD BANYUMAS
}

THE ANALYSIS OF FACTORS RELATED TO FOOD INTAKE ON THALASSEMIA PATIENT IN BANYUMAS HOSPITAL

\author{
Betty Irmawati ${ }^{1}$; Agus Prastowo ${ }^{2}$; J. Supadi ${ }^{3}$ Mohammad Jaelani $^{4}$; dan Yuniarti ${ }^{5}$ \\ ${ }^{1}$ Mahasiswa Jurusan Gizi Poltekkes Kemenkes Semarang \\ ${ }^{2}$ RSUD Prof. Dr. Margono Soekarjo \\ ${ }^{3,4,5}$ Dosen Jurusan Gizi Poltekkes Kemenkes Semarang
}

\begin{abstract}
Background : Nutritional deficiencies in long time can impair growth in thalassemia children, and the low energy reserves and existence of hypercatabolic make nutrition status of children leading to wasting condition. Result of initial survey in Instalation of Integrated Thalassemia Service, Banyumas Hospital, energy intake on thalassemia patient $54 \%$ is deficiency category.
\end{abstract}

Objective : To find factors related to food intake on thalassemia patient who receive regular blood transfusion in Banyumas Hospital.

Methods : The kind of research is inferential with cross sectional design. The number of subject is 57 patients, age 6-15 years. Statistic analysis is used to chi square test.

Results : The part of subject energy intake is deficit, with mean of energy intake is $85,74 \pm 13,62 \%$ AKG. All of subject do not experience side effect of gastrointestinal disturbance from consuming iron chelation. 66,7\% subject consume supplement according to doctor prescription, 57,9\% subject have good of nutrition knowledge, and $63,2 \%$ subject get good support from family. Result of statistic analysis is $p$ value for consuming supplement variabel is 0,003; 0,57 for nutrition knowledge and 0,01 for family support.

Conclusion: There are relation about consuming supplement and family support with food intake, but there are no relation about nutrition knowledge with food intake.

Keywords : thalassemia, food intake, family support

\section{ABSTRAK}

Latar Belakang : Kekurangan gizi dalam waktu lama dapat menyebabkan lambatnya pertumbuhan pasien thalassemia, serta cadangan energi yang rendah dan adanya hiperkatabolik mengakibatkan status gizi anak menjadi kurus. Hasil survey pendahuluan di Instalasi Pelayanan Thalasemia Terpadu RSUD Banyumas, 54\% pasien thalassemia asupan energinya termasuk dalam kategori kurang.

Tujuan Penelitian : Mengetahui faktor-faktor yang berhubungan dengan asupan makanan pasien thalasemia yang menjalani transfusi rutin di RSUD Banyumas.

Metode Penelitian : Jenis penelitian ini adalah inferensial dengan rancangan cross sectional. Jumlah subjek penelitian adalah 57 pasien usia 6-15 tahun. Uji statistik yang digunakan adalah uji chi square.

Hasil :Hasil penelitian menunjukkan hampir sebagian subjek asupan makannya dalam kategori kurang, dengan rerata asupan energi mencapai $85,74 \pm 13,62 \%$ AKG. Seluruh subjek tidak mengalami pengaruh gangguan gastrointestinal dari konsumsi kelasi besi; 66,7\%subjek mengkonsumsi suplemen sesuai dengan preskripsi dokter; 57,9\% subjek memiliki pengetahuan gizi yang baik serta 63,2\% subjek memperoleh dukungan keluarga yang baik. Hasil uji statistik diperoleh nilai p untuk variabel konsumsi suplemen 0,003 , pengetahuan gizi 0,57 , dan dukungan keluarga 0,01.

Kesimpulan : Ada hubungan konsumsi suplemen dan dukungan keluarga dengan asupan makanan pasien thalassemia, serta tidak ada hubungan pengetahuan gizi dengan asupan makanan pasien thalassemia. 


\section{PENDAHULUAN}

Kekurangan gizi sering terjadi pada pasien thalasemia, karena adanya anemia hemolitik, peningkatan kebutuhan gizi dan penyakit akibat kelebihan zat besi dan penggunaan kelasi. ${ }^{1}$ Thongkijpreecha et al,menunjukkan dalam penelitiannya rerata asupan makanan pasien thalasemia lebih rendah dari asupan makanan yang dianjurkan (1600 - 1700 kkal/hari). ${ }^{2}$ Serupa dengan hasil penelitian dari Tanphaichitr et al, di Thailand bahwa rerata asupan energi anak-anak dengan thalasemia hanya $65 \%$ dari RDA (Recommended Dietary Allowance). ${ }^{3}$

Fung et al, menunjukkan hasil penelitiannya tentang pola asupan makan pasien thalasemia dimana lebih dari $30 \%$ pasien, asupan vitamin $A, D, E, K$, folat, kalsium dan magnesium tidak adekuat. Rerata sajian makanan lebih rendah dari yang dianjurkan, terutama sajian dairy product (susu, yogurt, keju) dan whole grain (cereal, gandum, roti). ${ }^{4}$ Kekurangan gizi dalam waktu lama dapat menyebabkan lambatnya pertumbuhan pasien thalasemia, serta kondisi dimana cadangan energi yang rendah dan adanya hiperkatabolik pada pasien thalasemia membuat otot tubuh dipecah menjadi sumber energi hingga status gizi anak menjadi kurus. ${ }^{2}$

Instalasi Pelayanan Thalasemia Terpadu merupakan salah satu unit pelayanan terpadu di RSUD Banyumas, yang memberikan pelayanan komprehensif kepada pasien thalassemia. Dari hasil survey pendahuluan yang dilakukan secara acak pada 13 pasien thalassemia, diperoleh data $54 \%$ pasien asupan energinya termasuk dalam kategori kurang (kurang dari 80\% kebutuhan).

Tujuan dari penelitian ini adalah untukmengetahui faktor-faktor apa yang berhubungan dengan asupan makanan pasien thalasemia yang menjalani transfusi rutin di RSUD Banyumas. Penelitian ini bermanfaat untuk memberikan informasi bagi mahasiswa dan dietisien mengenai faktor-faktor yang berhubungan dengan asupan makan pasien thalassemia sehingga mempermudah dalam pemberian edukasi dan konseling gizi pada pasien thalassemia, bagi Rumah sakit dapat sebagai bahan pertimbangan pembuatan usulan kebijakan terkait pemberian intervensi gizi di Instalasi Pelayanan Thalasemia Terpadu serta dapat menambah pengetahuan dan memberikan informasi pada peneliti selanjutnya mengenai intervensi gizi yang dapat diberikan oleh dietisien pada pasien thalassemia.

\section{METODE PENELITIAN}

Ruang lingkup penelitian ini adalah bidang ilmu gizi klinik, yang dilaksanakan di Instalasi Pelayanan Thalasemia Terpadu RSUD Banyumas pada bulan Juli 2017. Penelitian ini termasuk dalam kategori penelitian inferensial dengan rancangan cross sectional.Populasi pada penelitian ini adalah semua pasien thalasemia hingga akhir tahun 2016 yang menjalani transfusi rutin di Instalasi Pelayanan Thalasemia Terpadu RSUD Banyumas sejumlah 402 pasien. Subjek adalah bagian dari populasi yang memenuhi kriteria inklusi (Pasien thalassemia $\beta$ mayor rawat jalan yang menjalani transfusi rutin (berulang) 3-4 minggu sekali, usia 6-15 tahun, memperoleh terapi kelasi besi, memiliki catatan medis lengkap, mampu membaca dan menulis) dan bersedia dijadikan subjek penelitian. Sedangkan kriteria eksklusinya adalah subjek yang mengalami penurunan kondisi selama waktu pengambilan data. Besar sampel penelitian dihitung dengan rumus penelitian analitik numerik tidak berpasangan, diperoleh besar sampel penelitian 57 subjek. ${ }^{5}$ Cara pengambilan subjek pada penelitian ini menggunakan teknik simple random sampling.

Data yang dikumpulkan meliputi identitas, konsumsi suplemen, pengetahuan gizi, dukungan keluarga dan asupan makanan. Cara pengumpulan data menggunakan alat bantu formulir identitas dan rekam medis pasien, metode wawancara dan metode angket.Asupan makanan diperoleh dengan analisis zat gizi dengan software Nutrisurvey 2007 berdasar data SQ-FFQ (Semi Quantitative Food Frequency Questionare) dengan metode wawancara terhadap responden dan subjek dengan alat bantu formulir SQ-FFQ. Uji statistik yang digunakan adalah uji chi square dengan derajat kepercayaan $95 \%$.

\section{HASIL DAN PEMBAHASAN}

RSUD Banyumas menjadi pusat pelayanan Thalassemia terpadu sejak 5 Mei 2009. Hingga akhir tahun 2016, pasien thalassemia sejumlah 402 pasien yang berasal dari daerah Banyumas, Cilacap, Purbalingga, Banjarnegara, Brebes, Kebumen, Pekalongan, Wonosobo, Pemalang, dan Tegal. Pelayanan yang diberikan di Instalasi Pelayanan Thalasemia terpadu meliputi pelayanan klinis (pelayanan thalasemia dari semua umur, meliputi tranfusi, pemberian kelasi besi, konsultasi 
dengan bidang-bidang terkait seperti ilmu kesehatan anak, ilmu kesehatan penyakit dalam, kardiovaskuler \& pembuluh darah, mata, syaraf, THT, kulit \& kelamin, bedah, kebidanan dan kandungan, rehabilitasi medik, gizi, serta psikologi), terapi bermain, monitor kelasi besi serta pelayanan pendidikan dan riset.

\section{Karakteristik Subjek}

Tabel 1. Karakteristik Subjek Penelitian di Instalasi Pelayanan Thalasemia Terpadu RSUD Banyumas Tahun 2017

\begin{tabular}{ccc}
\hline Karakteristik Subjek & $\mathbf{n}$ & $\%$ \\
\hline Jenis Kelamin & & \\
\hline Laki-laki & 27 & 47,4 \\
\hline Perempuan & 30 & 52,6 \\
\hline Jumlah & 57 & 100 \\
\hline Umur & & \\
\hline $6-10$ tahun & 22 & 38,6 \\
\hline $11-15$ tahun & 35 & 61,4 \\
\hline Jumlah & 57 & 100 \\
\hline Tingkat Pendidikan & & \\
\hline Tidak sekolah & 2 & 3,5 \\
\hline TK & 2 & 3,5 \\
\hline SD & 30 & 52,6 \\
\hline SMP/sederajat & 21 & 36,8 \\
\hline SMA/sederajat & 2 & 3,5 \\
\hline Jumlah & 57 & 100 \\
\hline Lama Transfusi & & \\
\hline$<1$ tahun & 4 & 7,0 \\
\hline $1-5$ tahun & 13 & 22,8 \\
\hline $6-10$ tahun & 25 & 43,9 \\
\hline$>10$ tahun & 15 & 26,3 \\
\hline Jumlah & 57 & 100 \\
\hline
\end{tabular}

Berdasarkan tabel 1, dapat diketahui bahwa karakteristik subjek penelitian terdiri dari 30 pasien $(52,6 \%)$ berjenis kelamin perempuan, 35 pasien $(61,4 \%)$ berada pada kisaran umur 11 - 15 tahun. Dari tingkat pendidikan yang sedang dijalani subjek, 30 pasien $(52,6 \%)$ berada pada tingkat Sekolah Dasar (SD) dan 2 pasien (3,5\%) saat ini tidak sekolah. Menurut lama transfusi, 25 pasien $(43,9 \%)$ dari 57 subjek sudah menjalani transfusi selama 6-10 tahun.

Penelitian ini sesuai dengan hasil penelitian Rejeki et al, yang menunjukkan dalam penelitiannya mengenai studi epidemiologi deskriptif thalassemia dimana $51,6 \%$ dari 163 pasien berjenis kelamin perempuan. Thalassemia merupakan penyakit genetik yang disebabkan oleh faktor alel tunggal autosomal resesif, bukan penyakit genetik yang disebabkan oleh faktor alel terpaut dengan kromosom seks/kelamin. ${ }^{6}$

\section{Karakteristik Responden}

Tabel 2. Karakteristik Responden di Instalasi Pelayanan Thalasemia Terpadu RSUD Banyumas Tahun 2017

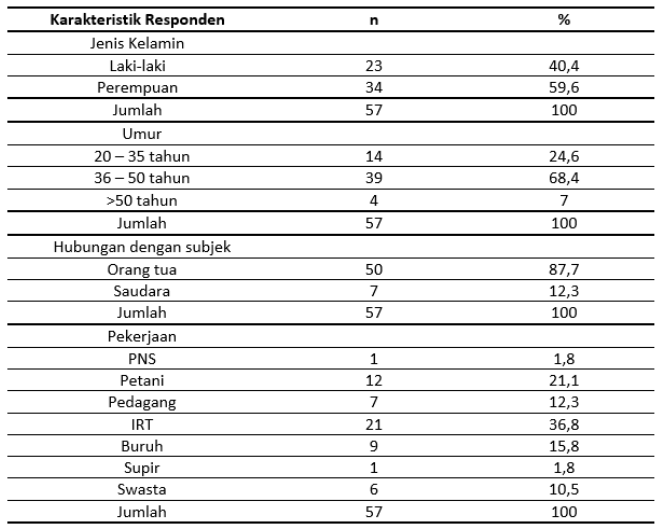

Berdasarkan tabel 2, dapat diketahui karakteristik responden yang mendampingi subjek saat pengambilan data yaitu $59,6 \%$ berjenis kelamin perempuan dan $68,4 \%$ berada pada kisaran umur 36 - 50 tahun. Hubungan $87,7 \%$ responden merupakan orang tua subjek, $36,8 \%$ responden merupakan Ibu rumah tangga.

\section{Data Penunjang}

Pemeriksaan kadar ferritin pasien thalassemia dilakukan tiap 3 bulan sekali untuk memonitor efektivitas terapi kelasi besi.

Tabel 3. Distribusi Subjek Penelitian Berdasarkan Kadar $\mathrm{Hb}$ pre-transfusi dan Kadar Ferritin Pasien di Instalasi Pelayanan Thalasemia Terpadu RSUD Banyumas Tahun 2017

\begin{tabular}{ccccc}
\hline Data Penunjang & $\mathbf{n}$ & \multicolumn{3}{c}{ Nilai } \\
\cline { 2 - 5 } & & Mean \pm SD & Minimum & Maksimum \\
\hline $\begin{array}{c}\text { Kadar Hb pre-transfusi } \\
(\mathrm{g} / \mathrm{dll})\end{array}$ & 57 & $7,63 \pm 0,97$ & 5,4 & 9,3 \\
\hline Kadar Feritin $(\mu \mathrm{g} / \mathrm{dl})$ & 57 & $4089,35 \pm 2969,18$ & 617,29 & $>12000$ \\
\hline
\end{tabular}

\section{Asupan Makanan Pasien Thalasemia}

Tabel 4. Distribusi Subjek Penelitian Berdasarkan Asupan Makanan di Instalasi Pelayanan Thalasemia Terpadu RSUD Banyumas Tahun 2017

\begin{tabular}{ccc}
\hline $\begin{array}{c}\text { Kategori } \\
\text { Asupan Makanan }\end{array}$ & $\mathbf{n}$ & $\%$ \\
\hline Kurang & 26 & 45,6 \\
\hline Baik & 31 & 54,4 \\
\hline Jumlah & 57 & 100 \\
\hline
\end{tabular}

Berdasarkan tabel 4, dapat diketahui bahwa 26 pasien $(45,6 \%)$ termasuk dalam kategori asupan kurang (kurang dari $80 \%$ AKG). Hasil penelitian ini sejalan dengan hasil penelitian Tanphaichitr et al, yang 
menunjukkan pasien anak-anak dengan thalassemia di Thailand, rerata asupan energinya hanya memenuhi $65 \%$ dari RDA (Recommended Dietary Allowance). ${ }^{3}$

Fuchs et al, menunjukkan dalam penelitiannya bahwa asupan energi pasien thalassemia lebih rendah dari RDA $(420 \mathrm{~kJ} / \mathrm{kg}$ per hari) sebelum atau sesudah rawat inap. $\mathrm{Hal}$ ini menunjukkan kurangnya asupan makanan menyebabkan asupan zat gizi tidak adekuat, sehingga berkontribusi pada status gizi pendek anak-anak dengan thalassemia mayor. ${ }^{7}$ Hasil dari wawancara dengan menggunakan metode SQ-FFQ, dapat diketahui secara umum, pola makan pasien thalassemia kurang seimbang, dimana sebagian besar pasien tidak menyukai sayur dan buah serta sering konsumsi jajanan dengan kandungan gula tinggi. Untuk bahan makanan daging merah (daging sapi, daging kambing) jarang digunakan karena harga yang relatif lebih mahal dan tinggi kandungan zat besi. Namun, bahan makanan hati ayam/ampela masih cukup sering digunakan sebagai alternatif sumber protein yang dikonsumsi pasien thalassemia.

Bahan makanan tinggi kalsium yang dianjurkan pada pasien thalasemia seperti susu, ikan dan keju termasuk jarang dikonsumsi, kurang lebih hanya 1-2x/minggu, serta ada beberapa subjek yang tidak menyukai susu. Fung et al, menyebutkan dalam penelitiannya bahwa keterbatasan asupan dairy product (susu, yogurt, keju) yang merupakan sumber utama kalsium, vitamin D dan magnesium, dapat meningkatkan resiko osteoporosis. ${ }^{4}$ Sebagian pasien thalassemia yang rutin transfusi mempunyai massa tulang yang rendah dan beresiko tinggi terjadinya fraktur. ${ }^{8}$

Tabel 5. Distribusi Asupan Makanan di Instalasi Pelayanan Thalasemia Terpadu RSUD Banyumas Tahun 2017

\begin{tabular}{|c|c|c|c|}
\hline Asupan Makanan & Mean $\pm S D$ & Minimum & Maksimum \\
\hline Asupan Energi (kkal) & $1758,41 \pm 260,81$ & 1157,5 & 2310,80 \\
\hline $\begin{array}{l}\text { Kecukupan Energi } \\
\text { (kkal/hari) }\end{array}$ & $2067,10 \pm 238,72$ & 1600 & 2475 \\
\hline \%Asupan Energi & $85,74 \pm 13,62$ & 54,47 & 123,44 \\
\hline \multicolumn{4}{|l|}{ Makronutrien } \\
\hline Protein (gr) & $65,36 \pm 12,58$ & 44,20 & 99,10 \\
\hline Lemak (gr) & $60,71 \pm 12,56$ & 37,6 & 93,70 \\
\hline Karbohidrat (gr) & $239,75 \pm 48,83$ & 113,3 & 377,50 \\
\hline \multicolumn{4}{|l|}{ Vitamin } \\
\hline Vitamin E (mg) & $110,09 \pm 55,16$ & 2,3 & 142,00 \\
\hline Vitamin C (mg) & $120,89 \pm 85,14$ & 20,30 & 514,90 \\
\hline Asam folat $(\mu \mathrm{g})$ & $200,74 \pm 69,92$ & 89,60 & 413,3 \\
\hline \multicolumn{4}{|l|}{ Mineral } \\
\hline Zat besi (mg) & $12,01 \pm 4,04$ & 5,6 & 22,00 \\
\hline Kalsium (mg) & $405,52 \pm 190,68$ & 125,40 & 1167,90 \\
\hline Zinc (mg) & $7,95 \pm 6,61$ & 4,30 & 39,50 \\
\hline Magnesium (mg) & $270,68 \pm 84,36$ & 129,70 & 470,70 \\
\hline
\end{tabular}

Berdasarkan tabel 5, rerata asupan energi subjek penelitian sudah memenuhi kecukupan energi yang dianjurkan dalam AKG 2013, dimana rerata presentase asupan energi subjek mencapai $85,74 \pm 13,62 \%$. Hal ini cukup jauh berbeda dengan penelitian Fung et al, dimana rerata asupan energi pasien thalassemia diantara $107 \%$ - 163\% dari estimasi kebutuhan berdasarkan usia, berat badan dan tinggi badan. ${ }^{4} \mathrm{Hal}$ ini dimungkinkan karena perbedaan karakteristik subjek penelitian dimana penelitian ini dilakukan di 10 klinik rawat jalan hematologi di Amerika Serikat dan Kanada yang merupakan negara maju. Selain itu, pada penelitian Fung et al, rerata usia subjek adalah 19,7 \pm 11,3 tahun yang termasuk kategori usia dewasa. ${ }^{4}$ Dalam penelitian Lucy dan Wardle menunjukkan adanya hubungan antara umur dengan pola konsumsi makan, dimana semakin tinggi umur semakin tinggi asupan makannya. ${ }^{9}$ Mirhosseini et al, menunjukkan dalam penelitiannya mengenai faktor yang mempengaruhi status gizi pasien thalassemia dimana asupan energi, makronutrien dan zat besi berkorelasi positif dengan semua parameter antropometri. Malnutrisi khususnya status gizi pendek dan penurunan massa otot, sering dijumpai pada pasien anak-anak dan remaja dengan thalassemia. ${ }^{10} \mathrm{Hasil}$ penelitian Mu'awanahmengenai gambaran status gizi pasien thalassemia di RSUP Dr. Kariadi Semarang menunjukkan status gizi anak dengan interpretasi BB/U sebanyak $57,1 \%$ gizi kurang dan menurut interpretasi TB/U 57,1\% termasuk kategori pendek. ${ }^{11}$

Sebagian besar pasien thalassemia tidak menyukai sayur, dan beberapa orang tua menghindarkan pasien thalassemia dari konsumsi sayuran hijau dikarenakan tinggi kandungan zat besi. Kurangnya asupan sayur dan buah pada pasien thalassemia dapat menyebabkan pasien thalassemia kekurangan serat dan zat gizi mikro seperti folat, vitamin $E$ dan $C$ sebagai antioksidan. Pasien thalassemia yang rutin transfusi beresiko mengalami peningkatan radikal bebas, sehingga dianjurkan untuk diet tinggi antioksidan. $^{12,13}$ Sayuran hijau merupakan bahan makanan yang tinggi antioksidan dan zat besi non-hem, oleh karenanya dianjurkan konsumsinya tidak bersamaan dengan vitamin C melainkan dengan teh. ${ }^{13}$ Buah, sayur dan gandum utuh tidak hanya diperlukan karena tinggi antioksidan 
melainkan serat dan folat yang berperan penting pada metabolisme sel darah merah. ${ }^{4}$

Penelitian Fung et al, juga menunjukkan tidak ada hubungan yang signifikan antara asupan zat besi dari makanan dengan simpanan zat besi total dilihat dari Liver Iron Concetration atau rerata pengukuran serum ferritin setelah dikoreksi umur, jenis kelamin, ras dan status transfusi. Ketika makanan yang tinggi zat besi dihindari, asupan zinc akan berkurang dimana zinc merupakan zat gizi ensensial yang khususnya berfungsi pada status imunitas, kesehatan tulang, dan pertumbuhan pasien thalassemia. ${ }^{4}$ Arijanty dan Nasar menjelaskan pemberian besi dalam bentuk elemen pada pasien thalassemia berusia dibawah 10 tahun sebaiknya dibatasi maksimal $10 \mathrm{mg} /$ hari, sedangkan di atas 10 tahun dibatasi maksimal $18 \mathrm{mg} /$ hari. $^{14}$ Transfusi darah terus menerus pada pasien thalassemia dapat mengakibatkan penimbunan zat besi dalam tubuh dan terjadinya hemosiderosis. Pembatasan asupan zat besi dianjurkan pada pasien yang tidak patuh menjalankan transfusi secara rutin dan memiliki kadar hemoglobin pre-transfusi yang sangat rendah (kurang dari 6 atau $7 \mathrm{~g} / \mathrm{dL}$ ) serta tidak patuh dalam konsumsi obat kelasi besi. ${ }^{12,13}$

5. Faktor-faktor yang berhubungan dengan Asupan Makanan Pasien Thalasemia

Tabel 6. Distribusi Subjek Penelitian berdasarkan Variabel Independen di Instalasi Pelayanan Thalasemia Terpadu RSUD Banyumas Tahun 2017

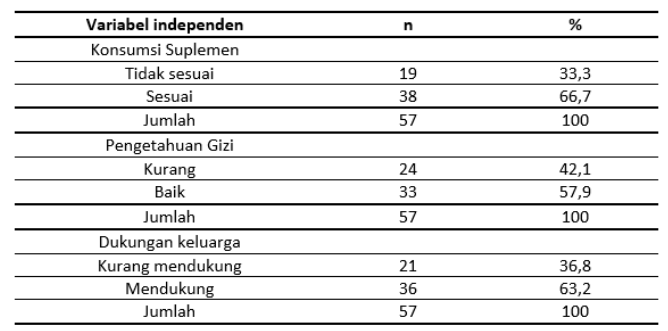

Jenis kelasi besi yang diperoleh subjek adalah feriprox (deferiprone) sejumlah 51 pasien dan jenis exjade (deferasirox) sejumlah 6 pasien.Berdasarkan hasil kuesioner dan wawancara dapat diketahui bahwa $42,1 \%$ subjek, konsumsi kelasi besinya tidak sesuai dengan preskripsi dokter. Hal itu dikarenakan kurangnya dukungan keluarga $(37,5 \%)$, faktor lupa $(33,3 \%)$, merasa bosan untuk konsumsi obat setiap harinya dalam jumlah yang cukup banyak $(20,9 \%)$ serta rasa obat (feriprox) yang pahit (8,3\%).

Seluruh subjek tidak mengalami pengaruh gangguan gastrointestinal yang ditegakkan sebagai diagnosa medis dokter. Namun, dari hasil wawancara, subjek terkadang merasakan efek samping obat kelasi besi berupa gangguan gastrointestinal diantaranya mual, nyeri perut dan perubahan nafsu makan. Pada tabel 6, diketahui bahwa terdapat 19 pasien $(33,3 \%)$ yang tidak sesuai dalam mengkonsumsi suplemen yang dipreskripsikan oleh dokter, hal tersebut dikarenakan subjek merasa bosan dengan jumlah obat yang harus dikonsumsi tiap harinya, faktor lupa serta beberapa subjek merasa tidak terlalu memerlukan suplemen tersebut.

6. Hubungan antara Konsumsi Kelasi Besi, Konsumsi Suplemen, Pengetahuan Gizi dan Dukungan Keluarga dengan Asupan Makanan Pasien Thalasemia

Tabel 7. Distribusi Subjek Penelitian Berdasarkan faktor konsumsi suplemen, pengetahuan gizi, dan dukungan keluarga dengan asupan makanan Pasien di Instalasi PelayananThalasemia Terpadu RSUD BanyumasTahun 2017

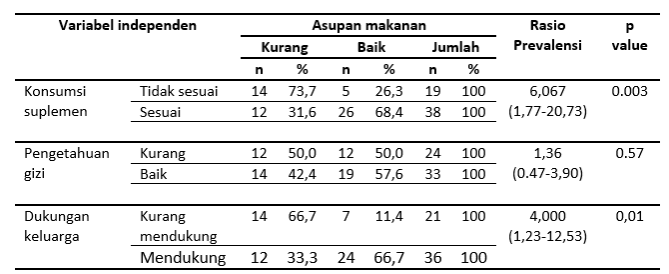

Berdasarkan tabel 7, dapat diketahui bahwa asupan makanan yang termasuk dalam kategori kurang terdapat pada subjek yang konsumsi suplemen tidak sesuai sebanyak $73,7 \%$. Hasil uji statistik diperoleh $p$ value 0,003 , dimana $p$ value $<0,05$ yang berarti ada hubungan antara konsumsi suplemen dengan asupan makanan pasien thalassemia yang transfusi rutin. Asupan makanan pasien terdiri dari zat gizi makro (protein, lemak dan karbohidrat) dan zat gizi mikro (vitamin dan mineral). Pada kondisi tertentu dimana tubuh membutuhkan zat gizi spesifik untuk meningkatkan kondisi kesehatan, dapat dipenuhi dari konsumsi suplemen. Hasil penelitian ini sesuai dengan penelitian yang dilakukan oleh Fung et al, dimana penggunaan multivitamin dan 
suplemen mineral secara rutin dapat meningkatkan asupan makan harian pasien thalassemia. ${ }^{4}$ Kesesuaian konsumsi suplemen pada pasien thalassemia akan meningkatkan asupan makanan pasien 6,07 kali lebih besar dibandingkan dengan konsumsi suplemen yang tidak sesuai.

Suplementasi asam folat berfungsi untuk mengurangi resiko thrombosis yang berhubungan dengan kadar homosistein dan aterosklerosis. Vitamin C berperan sebagai antioksidan yang dapat mengurangi kondisi akibat meningkatknya radikal besi bebas yang menyebabkan bahaya oksidatif. Sedangkansuplemen vitamin E berfungsi mengurangi stress oksidatif pada pasien thalassemia. $^{12}$ Vitamin $\mathrm{C}$ juga dapat meningkatkan efek kelasi besi deferoksamin (injeksi), namun jika diberikan dalam dosis berlebih dapat meningkatkan toksisitas zat besi. Vitamin $\mathrm{C}$ diketahui juga dapat meningkatkan absorpsi zat besi dari makanan, sehingga pasien perlu memperhatikan asupan zat besi yang difortifikasi dalam produk makanan. ${ }^{13}$

Hasil uji statistik yang menunjukkan nilai $p<0,05$ sehingga dapat diartikan konsumsi suplemen berhubungan dengan asupan makanan pasien thalassemia, sesuai dengan penelitian yang dilakukan oleh Fung et al, dimana penggunaan multivitamin dan suplemen mineral secara rutin dapat meningkatkan asupan makan harian pasien thalassemia. ${ }^{4}$ Vitamin berperan dalam beberapa tahap reaksi metabolisme energi, pertumbuhan dan pemeliharaan tubuh, sebagai koenzim atau sebagai bagian dari enzim. Sebagian besar koenzim terdapat dalam bentuk apoenzim, yaitu vitamin yang terikat dengan protein. ${ }^{15}$

Berdasarkan tabel 7, disebutkan pula asupan makanan yang termasuk dalam kategori kurang pada subjek dengan pengetahuan gizi kurang 50\%. Hasil uji statistik chi square diperoleh $p$ value 0,57 , dimana $p$ value $>0,05$ yang berarti tidak ada hubungan antara pengetahuan gizi dengan asupan makanan pasien thalassemia yang transfusi rutin. Hasil uji statistik Rank Spearman terhadap nilai pengetahuan gizi dihubungkan dengan prosentase asupan makanan diperoleh $p$ value 0,16 dengan nilai $r \quad 0,188$ yang berarti hubungan antara pengetahuan gizi dengan asupan makanan sangat lemah.

Aminah (2007) menunjukkan hasil penelitiannya dalam Mardhina bahwa ada hubungan antara tingkat pengetahuan gizi dengan pola konsumsi energi, protein, lemak dan karbohidrat yang artinya semakin tinggi tingkat pengetahuan maka akan semakin baik pola makannya. ${ }^{16}$ Berbeda dengan hasil penelitian Putri yang menunjukkan bahwa tidak ada hubungan antara pengetahuan gizi dengan pola konsumsi makan. ${ }^{17}$

Hairi menunjukkan dalam penelitiannya tidak ada korelasi yang bermakna antara pengetahuan gizi dengan asupan energi dan zat gizi pada pasien kanker, dikarenakan pengetahuan gizi merupakan faktor yang secara tidak langsung mempengaruhi konsumsi, terdapat beberapa faktor lain yang berpengaruh terhadap konsumsi diantaranya kesukaan, ketersediaan dan daya beli. ${ }^{18}$

Tidak ada hubungan antara pengetahuan gizi dengan asupan makanan pasien thalassemia dapat diasumsikan karena responden sudah sering memperoleh edukasi mengenai pembatasan bahan makanan tinggi zat besi. Oleh karenanya responden mampu menjawab dengan benar. Sementara dari asupan makanan pasien diperhitungkan dari asupan energi dimana $54,4 \%$ termasuk dalam kategori baik. Hal ini dapat pula dilihat dari hasil kuesioner dan wawancara dengan metode SQ-FFQ dimana sebagian besar responden mengetahui bahwa asupan bahan makanan tinggi zat besi perlu dibatasi, namun penggunaan bahan makanan tinggi zat besi hem seperti hati ayam masih cukup sering yaitu $\pm 2-3 x /$ minggu, sedangkan bahan makanan zat besi non-hem seperti sayuran hijau sangat dibatasi oleh responden dan beberapa ada yang menghindari.

Kesalahan persepsi ini perlu diluruskan dengan pemberian edukasi gizi yang benar secara rutin mengenai pengaturan makan pada pasien thalassemia, Dari hasil penelitian Sukmawati menunjukkan bahwa ada perbedaan tingkat pengetahuan sebelum dan sesudah edukasi berupa peningkatan pengetahuan responden yang artinya edukasi yang telah diberikan memiliki pengaruh terhadap perubahan pengetahuan responden. $^{19}$

Berdasarkan tabel 7, untuk variabel dukungan keluarga diketahui bahwa asupan makanan termasuk dalam kategori kurang pada $66,7 \%$ subjek yang kurang memperoleh dukungan keluarga. Dari hasil uji statistik menggunakan uji chi square diperoleh $p$ value 0,01 , dimana $p$ value $<0,05$ yang berarti ada hubungan antara dukungan keluarga dengan 
asupan makanan pasien thalassemia yang transfusi rutin. Hasil penelitian ini sejalan dengan hasil penelitian Tjahjono menunjukkan ada perbedaan yang signifikan dukungan keluarga baik dan kurang terhadap nafsu makan pasien, dimana hal ini berperan dalam pemenuhan kebutuhan gizi pada pasien kanker. ${ }^{20}$

Dukungan keluarga yang berkaitan dengan asupan makanan meliputi penyediaan dan pemilihan makanan, serta kepatuhan konsumsi kelasi besi dan suplemen. Pasien thalassemia yang rutin transfusi memperoleh zat besi dari darah transfusi lebih besar dari zat besi yang berasal dari makanan, sehingga pembatasan zat besi tidak menjadi fokus utama selama pasien patuh konsumsi kelasi besi. ${ }^{13}$ Secara jelas Fung et al, menjelaskan pasien memperoleh zat besi dari transfusi (200 mg besi/unit x 2 unit tiap $3 \mathrm{minggu}=19 \mathrm{mg} /$ hari) sangat jauh berbeda dengan zat besi dari makanan (rerata asupan zat besi : 12,5 $\mathrm{mg} /$ hari $\times 10 \%$ absorpsi $=1,25 \mathrm{mg} /$ hari). Pada kondisi kadar hemoglobin sangat rendah $(<9$ $\mathrm{g} / \mathrm{dL}$ ) absopsi zat besi meningkat dan dapat mencapai $20 \%{ }^{4}$

Hasil penelitian ini juga menunjukkan terdapat $42,1 \%$ subjek yang tidak sesuai dengan preskripsi dokter dalam konsumsi kelasi besi. Ketidaksesuaian ini berupa waktu konsumsi obat feriprox tidak dibagi menjadi 3x/hari karena kurangnya dukungan keluarga (orang tua bekerja di luar kota, tinggal dengan nenek/kakek yang kurang paham dengan obat-obatan), sering lupa, pasien jenuh minum obat dalam jumlah banyak dan rasa obat yang pahit. Kondisi ketidakpatuhan terapi kelasi besi ini memerlukan edukasi lebih lanjut mengenai pengaturan makanan pasien thalassemia. Supartini et al, menunjukkan bahwa faktor utama yang berkontribusi terhadap kualitas hidup anak dengan thalassemia adalah sikap keluarga dalam merawat anak thalassemia. ${ }^{21}$ Peran orang tua sangatlah berpengaruh pada asupan makanan anak dan status gizinya. ${ }^{22}$ Semakin baik dukungan keluarga akan meningkatkan asupan makanan pasien thalassemia 4 kali lebih besar dari pasien yang kurang memperoleh dukungan keluarga.

\section{KESIMPULAN DAN SARAN}

\section{KESIMPULAN}

1. Ada hubungan yang bermakna antara konsumsi suplemen dengan asupan makanan pasien thalassemia, dengan nilai p 0,003 dimana kesesuaian konsumsi suplemen dengan preskripsi dokter pada pasien thalassemia akan meningkatkan asupan makanan 6,07 kali lebih besar dari yang tidak sesuai.

2. Tidak ada hubungan yang bermakna antara pengetahuan gizi dengan asupan makanan pasien thalassemia, dengan nilai $p 0,57$.

3. Ada hubungan yang bermakna antara dukungan keluarga dengan asupan makanan pasien thalassemia, dengan nilai p 0,01 dimana semakin baik dukungan keluarga akan meningkatkan asupan makanan pasien thalassemia 4 kali lebih besar dari dukungan keluarga yang kurang.

\section{SARAN}

1. Perlunya pemberian edukasi secara rutin kepada keluarga pasien thalassemia mengenai pola asuh yang baik untuk meningkatkan kepatuhan konsumsi obat kelasi besi dan suplemen guna meningkatkan kualitas hidup pasien thalassemia.

2. Perlunya kolaborasi dengan tenaga kesehatan lain terkait dengan kepatuhan penggunaan obat dan suplemen, serta terapi transfusi pada pasien thalassemia.

3. Perlunya peningkatan intervensi gizi dari Instalasi Gizi terkait dengan edukasi gizi mengenai operasional pengaturan makanan pada pasien thalassemia terutama asupan zat gizi mikro (vitamin dan mineral).

4. Perlunya penelitian lebih lanjut mengenai intervensi gizi berupa modifikasi diet rendah besi yang dapat diberikan pada pasien thalassemia

\section{DAFTAR PUSTAKA}

1. Vichinsky, MD. E, et al. 2012. Standards of Care Guidlines for Thalassemia. Oakland : www.childrenhospitaloakland.org. 6 Oktober 2016 (05.50).

2. Thongkijpreecha, P., Kangsadalampai, O., Pongtanakul, B., and Meksawan, K.2011. "Nutritional Status in Patients with Thalassemia Intermedia," Journal HematologyTransfuse Medicine ; 21, 167-176.

3. Tanphaichitr, V.S., Visuthi, B., Tanphaichitr, V. 1995. "Causes of Inadequate Protein-Energy Status in Thalasemic Children," Asia Pacific Journal Clinical Nutrition ; 4, 133-135. 
4. Fung, E.B., Yan Xu, Trachtenberg, F., Odame, I.,Kwiatkowski, J.L., Neufeld, E.J., Thompson, AA., Boureaux, J., Quinn, C.T., Vichinsky, E.P. 2012. "Inadequate Dietary Intake in Patients with Thalasemia," Journal of the Academy of Nutrition and Dietetics Vol. 112 No. 7, 980990.

5. Dahlan, M.S. 2013. Besar Sampel dan Cara Pengambilan Sampel dalam Penelitian Kedokteran dan Kesehatan edisi 3. Jakarta : Salemba Medika, 68-75.

6. Rejeki, D.S.S., Nurhayati, N., Supriyanto, Kartikasari, E. 2012. "Studi Epidemiologi Deskriptif Thalasemia," Jurnal Kesehatan Masyarakat Nasional Vol. 7 No.3. 139-144.

7. Fuchs, GJ., Tienboon, P., Khaled, M.A., Nimsakul, S., Linpisarn, S., Faruque, A.S.G., Yutrabootr, Y., Dewier, M., dan Suskind, RM. 1997. "Nutritional Support and growth in Thalassaemia," Archives of Disease in Childhood; 76, 509-512.

8. Vogiatzi, M., Macklin, EA., Fung, EB., et al. 2009. "Bone Disease in Thalasemia : A Frequent and Still Unresolved Problem". Journal Bone Miner Research : 24(3), 543557.

9. Lucy J., C. dan Wardle, J. 2005. “Age and Gender Differences in Children's Food Preferences," British Journal of Nutrition, 93, 741-746.

10. Mirhosseini, N., Kamaruddin, N.A., Mobarhan, M.G., dan Esmaily, H. 2013. "Factors Affecting Nutritional Status Among Pediatric Patients with TransfusionDependent Beta Thalasemia," Mediterranean Journal of Nutrition and Metabolism. 6 : 4551.

11. Mu'awanah. 2015. Gambaran Status Gizi Pasien Thalasemia di RSUP Dr. Kariadi Semarang. Skripsi telah diterbitkan. Semarang : http://lib.unimus.ac.id. 4 Agustus 2017 (10.54).

12. Angastiniotis, A.M. 2014. "Lifestyle and Quality of Live," Guidelines for The Management of Transfussion Dependent Thalassemia (TDT) $3^{\text {rd }}$ edition. Cyprus: Thalassemia International Federation.

13. Baer, K. 2013. "A Guide to Living with Thalassemia," Cooley's Anemia Foundation.www.thalassemia.org. $\quad 14$ September 2016 (22.49).

14. Arijanty, L. dan Nasar, S.R. 2003. "Masalah Nutrisi pada Thalasemia," Sari Pediatri Vol. 5 No.1, 21-26.

15. Almatsier, S. 2001. Prinsip Dasar Ilmu Gizi. Jakarta: Gramedia Pustaka Utama, 28-254.
16. Mardhina, S. 2014. Hubungan Pengetahuan Gizi dan Body Image dengan Frekuensi Konsumsi Fast Food Remaja Putri di SMK N 4 Surakarta. Skripsi telah dipublikasikan. Surakarta : http://eprints.ums.ac.id. 13 Agustus 2017 (06.07).

17. Putri, AY. 2015. Faktor-faktor yang berhubungan dengan Pola Konsumsi Makan pada Siswa Madrasah Ibtidaiyah Unwanul Huda di Jakarta Selatan Tahun 2015. Skripsi telah diterbitkan. Jakarta : http://repository.uinjkt.ac.id. 25 Desember 2016 (07.07).

18. Hairi, SL. 2013. Faktor-faktor yang berkaitan dengan Asupan Energi dan Zat Gizi Pasien Kanker di Rumah Sakit Kanker Dharmais. Skripsi telah diterbitkan. Jakarta. Bogor : http://repository.ipb.ac.id. 6 Agustus 2017 (02.37).

19. Sukmawati, T., Syam, A., dan Najamuddin, U. 2013. Pengaruh Edukasi Gizi terhadap Perubahan Pengetahuan dan Asupan Zat Gizi pada Anak Gizi Lebih di SDN Sudirman I Makasar Tahun 2013. Skripsi telah diterbitkan. Makasar http://repository.unhas.ac.id. 23 Januari 2017 (09.31).

20. Tjahjono, HD. 2011. Analisis Faktor-faktor yang MempengaruhiNafsu Makan pada Pasien dengan PenyakitPernafasan Obstruksi Kronisdi RSUD Dr. M. SoewandhieSurabaya. Tesis telah diterbitkan. Depok : http://lib.ui.ac.id. 21 Januari 2017 (10.45).

21. Supartini, Y., Sulastri, T. dan Sianturi, Y. 2013. "Kualitas Hidup Anak yang Menderita Thalasemia," Jurnal Keperawatan Vol.1 No.1, 1-11.

22. Marshall, S., Golley, R. dan Hendrie, G. 2011. "Expanding the Understanding of How Parenting Influences the Dietary Intake and Weight Status of Children : A Crosssectional Study," Nutrition and Dietetics ; 68, 127-133. 